\title{
Student Perception of Online Learning in ESL Bilingual Teacher Preparation
}

\author{
Mayra C. Daniel ${ }^{1, *}$, Gail Schumacher ${ }^{1}$, Nicole Stelter ${ }^{2}$, Carolyn Riley ${ }^{1}$ \\ ${ }^{1}$ College of Education, Department of Literacy and Elementary Education, Northern Illinois University, USA \\ ${ }^{2}$ College of Education, Department of Counseling, Adult, Higher Education, Northern Illinois University, USA
}

Copyright $\mathrm{O} 2016$ by authors, all rights reserved. Authors agree that this article remains permanently open access under the terms of the Creative Commons Attribution License 4.0 International License

\begin{abstract}
Current technologies are changing delivery options for post-graduate teacher education. Many practicing teachers who return to school to prepare to educate English learners choose distance learning. This article explores teachers' perceived satisfaction with the quality of online courses, with the collaborative tasks required in these, and the extent to which the teachers consider the online course format effectively prepares them to work with English learners. This study reports qualitative and quantitative finding from a questionnaire administered to teachers who completed graduate level courses in an online format. Data gathered strongly support online course delivery as a viable and appropriate format for post-graduate teacher preparation. Study findings are encouraging for the effectiveness of online course formats to prepare practicing teachers. Responses on the survey questionnaire completed by participants document their perception that online courses are as rigorous as F2F coursework given effective online delivery formats that include appropriate instructor availability, timely and positive feedback, and flexible course organization.
\end{abstract}

Keywords Asynchronous Learning, Online Courses, Teacher Preparation, English Learners

\section{Introduction}

Today there is an excitement at the Ivory Tower because online learning is offering many innovative paths to completing post-graduate work for practicing teachers. These educators are able to work toward advanced degrees from the comfort of their homes in both synchronous and asynchronous formats (Patrick \& Powell, 2009 [20]). Professors challenge themselves to develop online instructional formats that are cognitively demanding, engaging, and enroll students to reflect upon their work so that they, in turn, will design high quality instruction for their
K-12 student populations (Ward, Peters, \& Shelley, 2010 [31]). While the professoriate welcomes the opportunity to explore new instructional paradigms, they want to be certain their students are satisfied with the non-traditional course delivery formats.

This study considers the current demands being placed on tertiary educators to offer the same coursework in online courses that is part of curriculums in face-to-face (F2F) delivery formats; especially methods courses for teachers preparing to work with English learners (ELs). In spite of the demand for online programs, some professors resist the teaching of methods courses online (Allen \& Seaman, 2013 [4]; McNeals, 2015 [14]). Some researchers argue that online formats cannot effectively promote critical conversations and that this results in a decrease in instructor and program effectiveness (Stephen, 2001 [25]; Swan, 2003 [26]; Xu \& Jaggars, 2013 [33]). Other scholars have suggested the opposite to be true and that graduate students are satisfied with distance education (Garner, Pack, Szirony \& Beeson, 2013 [11]; Sampson, Leonard, Ballenger \& Coleman, 2010 [23]).

Numerous challenges affect this burgeoning growth of online offerings at the post-graduate level. One is the quality of institutional support for course development and delivery when technology challenges may affect both student and instructor satisfaction (Neal, 2015 [17]). In addition, there are problems with course ownership. Professors who develop a course may not wish to share their work for use by another instructor. Similarly, it may seem prescriptive to an instructor to be required to incorporate materials in their courses that have been designed by another professor (Kearsley, 2005 [13]; McNeals, 2015 [14]).

This study investigates practicing teachers' perceptions of online course formats and asks whether or not the courses effectively helped them learn. Specifically, this study examines teachers' perceived level of effectiveness of online methods courses to prepare to work with English learners (ELs) and their satisfaction with the post-graduate courses they completed that constitute the focus of this study's 
instructional evaluation. This research also explored if the teaching, learning, and evaluation in the online courses that composed this study resulted in satisfactory levels of student engagement, thinking, and meaning making. Data gathered is used to evaluate teachers' self-reports related to what constitutes appropriate selection of readings and assignments, the quality of instructor feedback and communication, course organization and format, achievement of outcomes, and level of satisfaction with Required collaborations and group assignments using a Likert scale questionnaire. Specifically, this study explored teachers' perceived satisfaction with online course formats as a path to become highly qualified educators of ELs and their reasons for enrolling in online rather than face to face (F2F) courses.

\section{Literature Review}

The changing demographics have resulted in practicing teachers flocking to universities with the goal of preparing to work with ELs (Allen \& Seaman, 2010 [2]; Bates, 2011 [5]; Van Der Werf \& Sabatier, 2009 [30]). It seems plausible to consider that the teachers are enrolling in online methods courses because these fit their working schedules. The question is not whether the online platforms need to be offered in the $21^{\text {st }}$ century, but to identify how to do so in an effective way to ensure teachers are satisfied and the learning is demanding and prepares them well to work with ELs (Palloff \& Pratt, 2011 [19]). Thus, the overarching question guiding this study is the following: Are online courses an effective method for preparing teachers to work with English learners?

\subsection{Learning Outcomes}

In the past 15 to 20 years, several studies have found that online learning has shown favorable outcomes in terms of student learning when compared with F2F classes. A United States Department of Education (2010 [29]) meta-analysis of online learning studies found that students who took the online course, performed better, on average, than those taking the same course in a F2F format. It was noted, however, that the effect sizes were larger for studies in which there was collaboration or direct instruction by instructor rather than solely independent work. Reporting on twenty years of research of online learning compared to $\mathrm{F} 2 \mathrm{~F}$ classes, Shachar \& Neumann (2010 [24]) found that students taking courses by distance education outperformed their student counterparts taking F2F courses. In a comparison of one section of online learning with one section of a F2F class, Neuhauser (2002 [18]) asserted that the quality of online learning was as effective as F2F learning. Studies at the college level have supported the findings that students learning through online mediums perform equally well or better than students taking F2F courses (Patrick \& Powell, 2009 [14]; Swan, 2003 [26]).

\subsection{Growth of Online Learning}

Research indicates that online learning offers students fast-paced and substantial growth. Allen and Seaman (2011 [3]) found that online courses increased by 21 percent between 2009 and 2010. This represented a growth of over one million students in just one year. Other researchers have found similar growth results (Bates, 2011[5]; Green, \& Wagner, 2011 [12]). The reasons for the expansion of online learning may be traced to the economic downturn (Allen \& Seaman, 2010 [2]), change in student demographics (Bates, 2011 [5]; Van Der Werf \& Sabatier, 2009 [30]), and availability of improved technology (Green \& Wagner, 2011 [12]). Van Der Werf \& Sabatier (2009 [30]) suggest that by the year 2020, students will be more diverse than ever before. The challenge to universities will be to offer courses that meet the technological needs of a new generation of learners. Without doubt, online learning platforms will be a part of this future.

\subsection{Cost of Online Learning}

The majority of current research on distance learning has compared the cost of delivering online instruction to that of a traditional classroom. Twigg (2001 [28]) offered evidence that online learning can be cost effective provided the courses are redesigned to increase enrollment while still maintaining high levels of rigor. Twigg suggested that a well-designed online model planned by full-time faculty and taught by part-time faculty could reduce the delivery costs of online learning. Meyer (2008 [16]) cautions that even though there is evidence that online learning is cost effective, funds still need to be available to transition from traditional to online course delivery. Given economic issues, state tax structures limiting support of public universities, and governmental reluctance to fund higher education, the funding of online learning may fall solely to the universities. Bates (2011 [5]) argues that in spite of funding issues, online course offerings are more cost effective in the long run than traditional models.

\subsection{Past, Present, and Future of Online Instruction}

Much research has focused on examining the demand and quality of student learning in online courses (Patrick \& Powell, 2009 [20]; Neuhauser, 2002 [18]; Shacar \& Neumann, 2010). Students' satisfaction with the quality of online courses has been the focus of study (Garner et al., 2013 [11]). Researchers have compared the appropriateness of online formats for teacher preparation to F2F traditional instruction (Chiero \& Beare, 2010 [6]). Online formats that have been used to prepare teachers to teach foreign languages have been the subject of inquiries in English language teaching for many years (Compton, 2009 [7]). Prior work has documented the need for further research across all disciplines when teaching online areas and especially in programs of teacher preparation (Dede et al., 2009). A 
meta-analysis of online learning suggested academic achievement in online formats exceeds that of F2F courses (Means et al., 2009 [15]). It is also critical to acknowledge that research has not adequately examined tertiary instructor preparation to teach in online environments (Jones \& Youngs, 2006 [10]; Davis \& Rose, 2007 [8]; Wood, 2005 [32]), nor identified unequivocally the components needed for online delivery in methods courses to prepare teachers. Clearly, a research agenda is needed to examine online courses in post-graduate education that prepare teachers to work with ELs. This research opens the door to examining new paths to prepare teachers to work with ELs. It ensures the schoolhouse will respond to the educational needs of the changing demographics.

\section{Methods}

\subsection{Research Questions}

This investigation was designed with the goal of addressing the following three research questions focused on the use of online courses to prepare teachers to design and deliver effective instruction for ELs:

1. What components of online courses do students perceive facilitate collaboration, self-reflection and application of theory to practice?

2. What are the reasons teachers identify lead them to enroll in online courses?

3. Can online methods courses to prepare teachers to work with English learners effectively promote the type of self-reflection and collaborative engagement that impacts practice at levels K-12?

To address the study's questions, a participant questionnaire was developed after examining domains of knowledge and students' personal preference for course delivery protocols. These were documented in a meta-analysis of previous research focused on online instructional paradigms (Shacar \& Neumann, 2010) and in prior research on student satisfaction with online course formats (Rothman, Romeo, Brennan, \& Mitchell, 2011 [22]).

The following seven domains were identified:

1. Reasons participants identified led them to enrollment in the online courses.

2. Perceived appropriateness of course readings and assignments.

3. Accessibility of technology required to complete coursework.

4. Student perception of instructor feedback and communication.

5. Course organization and format meeting expectations for a graduate level course.

6. Student perception of achievement of intended outcomes in courses.
7. Effectiveness of assignments leading to collaborative work in the courses.

\subsection{Setting and Participants}

This study took place in a public rural Midwestern university situated about two hours from the city of Chicago, IL. The academic department that offers the post-graduate courses that participants in this study completed is part of the College of Education at the university. Online coursework that served as the vehicle to gather data in the questionnaire is aimed at preparing teachers and scholars to work and learn within multicultural and multilingual contexts as classroom teachers, reading specialists, and teachers of ELs, college/university professors, and policy makers in all facets of the education profession. Participants in the study (N: 47) were certified teachers completing graduate level courses to become highly qualified teachers of ELs. All participants voluntarily selected to complete the survey questionnaire that was sent to them. These teachers had completed four courses focused on linguistic and cultural factors in instructional planning for ELs: Foundations of Language-Minority Education, Multicultural Education Methods and Materials, Teaching English as a Second Language, and English Linguistics. Some of the participants completed one online course and submitted their questionnaire after the course. Some enrolled in two or more of the online courses: these teachers completed the survey more than once after completion of courses. In the State of Illinois, the site for this study, teachers are required to complete six courses to be considered highly qualified to work with ELs. In addition, to work as a bilingual teacher in Illinois, the educator is required to prove proficiency in the language other than English that will be used in their classroom through successful completion of an oral and written language proficiency examination administered by the state.

\subsection{Procedures}

A survey questionnaire was sent to students after they finished all tasks in the four online courses that composed the focus of this study and after their final grade was recorded on their university transcript. Four different professors taught the courses and not all students enrolled in the four courses. The coursework focused on increasing teacher expertise to design lessons for culturally and diverse students: courses addressed the cultural and linguistic influences on learning at levels K-12.

The survey questionnaire consisted of thirty-five Likert scale questions focused on the seven domains identified for this research. The domains to be analyzed were developed after consulting prior research on students' satisfaction with online courses (Rothman, Romeo, Brennan, \& Mitchell, 2011 [22]; Schacar \& Neumann, 2010). Questions on the survey questionnaire addressed reasons participants enrolled 
in the online courses, their judgment of the quality of the course readings and assignments, the technology used, the feedback they received from their instructors, the format of the courses, their satisfaction with the level of the learning and the collaborative components of the courses. Responses were examined by domain to establish how participant responses contributed to providing insights that would answer the three questions of this study.

\section{Results}

In this section of the paper, quantitative and qualitative data results from the survey questionnaire are organized into three sections to address the study questions. Appendix 1 presents the quantitative data divided into the seven domains identified in the research literature. Each question was scaled to obtain a response from five choices: Strongly Agree, Agree, Neutral, Disagree, and Strongly Disagree. Each response choice was then placed under the appropriate domain. The mean score was then obtained for each response choice within the respective domain and converted into the percentage of respondents and their choices within each domain. Secondly, responses to the open ended questions were examined for recurrent themes (Strauss \& Corbin, 1990 [27]). This data were examined in the subsections that address the study's questions.

Qualitative data were analyzed and recurrent themes identified as seen in Appendix 2. Two open-ended questions with a total of a 27 participant response count were analyzed. Responses to the open-ended questions ranged from one word answers to paragraph reflections. Six themes were determined, which include Feedback and Discussion, Individual Reflections, Course Organization and Format, Quality of the Instructor, Reasons for Enrollment, and Technology Use.

Appendix 2 presents the recurring themes in the two open-ended questions that asked the participants to identify one or two preferred assignments and to share comments about the online course.

Question 1: What components of online courses do students perceive facilitate collaboration, self-reflection and application of theory to practice?

Answers to the questions that focused on the Effectiveness of Technology used to deliver the courses revealed that a total of $80 \%$ of the participants reported the technology required was easy to use and $80 \%$ of the students also believed that the Blackboard platform was easy to navigate. Responses to questions addressing participant satisfaction with the Instructor Feedback reflect that $76 \%$ of participants reported that the instructor was available to fit their educational needs, $71 \%$ believed that the instructor's feedback was timely and informative and $74 \%$ responded that the instructor was accepting of their opinions.

The fifth domain discussed the course Format and Organization. While $74 \%$ of the respondents believed that the course they completed was more rigorous than a F2F course, $26 \%$ were neutral. In a similar question, respondents $(80 \%)$ shared that the course was as rigorous as a F2F course, with a $12 \%$ neutral response. The online courses were documented to be set at an appropriate pace for learning for $80 \%$ of the respondents and $74 \%$ of the participants believed that the courses were well organized and student friendly.

The seventh domain focused on Student Collaboration. Group work was reported to provide ideas to engage K-12 students in collaborative work (46\%): $31 \%$ of the participants did not agree with this statement. Although $29 \%$ of the teachers disagreed and 26\% where neutral, $59 \%$ believed group assignments helped them examine course content and clarify ideas and $51 \%$ believed the group work promoted professional development in their school district. The collaborative reflections were reported to have helped $66 \%$ of the participants apply theory to practice, with $26 \%$ disagreeing.

Question 2: What are the reasons teacher participants identified led them to enroll in online courses?

Although this question does not directly relate to the teachers' perception of the quality of the courses, this was an important factor to include in the survey questionnaire for other reasons. One of the researchers is the coordinator of the program that offers the Bilingual English as a Second language methods courses. She needed to know why students would enroll in the online courses rather than the F2F formats. She assumed students would be motivated to enroll in online courses if they lived a distance from the university campus. This was not the reality as many of the participants shared they

lived in communities close to the university.

For the first domain, Reasons for Enrollment, $87 \%$ of the respondents reported they appreciated the extra time provided by an online course to think and work to develop understandings as they linked course content to the classroom context: $76 \%$ of the participants reported their reason was that they were independent learners and $83 \%$ reported they find it easier and like to express their thoughts through writing. Answers to questions revealed the online format allowed $79 \%$ of the participants to balance coursework and their personal schedules. Interestingly, when the teachers were asked if they preferred the online course format over weekly F2F class meetings, $46 \%$ responded with agreement and $30 \%$ stated that they were neutral to this proposition.

Question 3: Can online methods courses to prepare teachers to work with English learners effectively promote the type of self-reflection and collaborative engagement that impacts practice at levels K-12?

The second domain addressed this question: the student's preference for the course Readings and Assignments. A total of $77 \%$ of responses suggest the readings made the participants think outside of the box, $83 \%$ of the teachers believed the readings challenged them to examine how they 
interact with their K-12 students, and $69 \%$ shared that the readings led them to change how they will interact with K-12 students in the future. The sixth domain addressed Student's Achievement of Outcomes. While $63 \%$ of the teachers believed that there was a good balance of group and individual assignments in the courses, $31 \%$ of the respondents disagreed with this proposition. A total of $74 \%$ of the participants responded that the course materials helped them examine their philosophical stances while $76 \%$ reported that course readings impacted their practice because they helped them examine what they do in their teaching.

\section{Discussion}

For the most part, responses to the survey questionnaire supported the online course format for preparing teachers to work with ELs. It is noteworthy that although four different instructors taught the courses, answers to the questionnaire indicate students were satisfied with the online format.

Question 1: What components of online courses do students perceive facilitate collaboration, self-reflection and application of theory to practice?

There was a $74 \%$ agreement that the online courses helped clarify the student's philosophical stances. The majority of the students were evenly distributed into those who agreed and those who disagreed with the quality of collaborative work in the online format. As compared to other results, findings are inconclusive in regards to the collaborative components as only $56 \%$ of the participants noted this was a strong piece of the online courses. This suggests the need for further research (Dede et al, 2009 [9]; Jones \& Youngs, 2006 [10]). It is possible that as the teachers participate in multiple online courses, we may see a trend as they gain familiarity with the online course format, group dynamics, and instructor feedback.

Even though the teachers did not respond that they had observed a link between theory and practice, responses to some of the items on the questionnaire strongly indicate that the online courses promoted professional development and encouraged the teachers to reflect about their work in the K-12 classroom (Garner et al., 2013 [11]). Responses to the qualitative questions revealed that the teachers were more engaged when they perceived the course material was related to their immediate professional development needs. This highlights the need to overtly help teachers make the link between theory and practice whether in F2F or online courses.

Question 2: What are the reasons teacher participants identified led them to enroll in online courses?

In analyzing the responses, it is evident that the teachers enrolled in the online courses due to choice, not necessarily related to balancing their other commitments on the evenings the classes were held and not because they lived a great distance from the university. It was noteworthy that $76 \%$ of the participants were under 40 years of age, which may have provided the $80 \%$ agreement response to familiarity with current technologies. Comfort and confidence when using current technologies may be what led the participants to self-select their enrollment in the $100 \%$ online courses.

Overall, participants were satisfied with the instructor feedback, with the exception of one course that was taught by an instructor who agreed to teach in the online format but later voiced a lack of commitment to exploring possible designs for teaching an online course. This highlights the ongoing need to address instructor preparation and willingness to modify F2F delivery for the online environment (Dede et al. 2009 [9]; Jones \& Youngs, 2006 [10]; Wood, 2005 [32]). It is not safe to assume all instructors are prepared to teach online or fully grasp that preparation for an online course may require additional time and a different skill set (Dede et al. 2009 [9]).

As shown in this study, there is a need for online course delivery for teachers working with English learners. The students were satisfied with the quality of the courses (Garner et al. 2013 [11]). Participants reported that they want more opportunities to enroll in online courses. Through the analyses of the qualitative questions, student's strongest

Motivation when enrolling in the online courses was identified as accommodating time commitments with family and work, instructor flexibility, and working at an individual pace. Living a distance from the university campus was not a factor. The questionnaire did not ask the teachers how many hybrid courses they had completed prior to enrolling in the $100 \%$ online format. This merits addressing in future research. As the researchers examined student enrollment in the semesters that followed this study, they noted many of the students continued to enroll in courses offered in hybrid formats.

Question 3: Can online methods courses to prepare teachers to work with English learners effectively promote the type of self-reflection and collaborative engagement that impacts practice at levels $\mathrm{K}-12$ ?

The students reported that the online courses were more or as rigorous as face-to-face formats (Means et al., 2009 [15]). In fact, $80 \%$ of the respondents believed that the courses were as much, if not more rigorous as face-to-face classes. Although the students desired to work individually, the online coursework appears to have challenged them in a positive way in both group and individual assignments.

Analyses of the qualitative recurrent themes document that the instructors' approachability, timely responses, and encouraging feedback were factors led the teachers to enroll in a second online course. The data suggest this is an important consideration. It is essential for all instructors to be fully committed to delivering online courses in order to engage teachers in high level professional development. Examining the appropriateness of course content and assignments is the key to ensuring a productive affective 
domain. While $63 \%$ of the respondents agreed that the course information presented by their instructors was scaffolded well, $23 \%$ were neutral. While voicing neutrality may capture the teachers' stance, one could hypothesize that a neutral response suggests a closer look is needed to better examine topic presentation in the courses.

Over $76 \%$ of the participants agreed that instructor availability and feedback met their needs. While $80 \%$ of the students responded that the technology required in the course was easy to use provided there was appropriate accessibility, it is important to note that $76 \%$ of the participants were 41 years old or less, an additional $20 \%$ were between 41 and 50 , and only $2 \%$ were over age 51 . This supports the need for instructors to be as informed of current technologies as their students.

\section{Conclusions}

The teachers who enrolled in the online courses felt comfortable communicating in the digital environment. In today's world, all of us communicate through online technologies, yet few of us stops to consider the amazing ways inter and intra-personal communication has changed in recent years. Today we can see, hear, and talk with folks synchronously across continents and only stop to react if the system we are using prevents us from chatting as quickly as we wish.

The online courses made it possible for the participants to learn the same way they communicate every day with their friends and families using email and social networking programs like Facebook. Delving into the scope of the participants' tasks in their online courses, one can hypothesize how their familiarity with online mediums may transfer to their own classrooms. We encourage teachers to work with their ELs while delivering multi-modal instruction. Technology integration helps teachers achieve this goal. It contributes to ELs' academic achievement because it supports their hybrid language practices.

This study's findings suggest that teachers' perception of online coursework is that it effectively helps them learn and is as rigorous as F2F coursework given appropriate levels of instructor availability, positive feedback, and flexible course organization. It seems probable that teachers enrolled in online methods courses will see a link between how they and their students learn using current technologies.

Data strongly suggest that moving to online learning requires implementing effective practices for developing, funding and sustaining the vitality of course offerings. As well, faculty competency demands training and ongoing support to implement current technologies. Power (2008 [21]) cautioned the Ivory Tower to examine the need for a fine balance between administrators' goals and faculty realities. Data gathered in this study indicates that successful online programs require a workplace friendly atmosphere that fosters collaboration. Abel's work (2005 [1]) agrees with this study's results that successful online curricular offerings closely correlate to universities' long-term commitment and support for faculty.

Thus, we conclude that offering graduate level online courses that prepare teachers to work with ELs is an appropriate and positive curricular response to teachers' voiced needs in graduate education. Teachers ask to be challenged, to increase their competencies, and to enroll in courses that allow them flexibility to complete readings, collaborate on tasks, and submit assignments at convenient times.

\section{Acknowledgements}

We want to thank the teachers who participated in this study. 


\section{Appendixes}

\section{Appendix 1. Quantitative Data}

\begin{tabular}{|c|c|c|c|c|c|c|}
\hline \multirow{2}{*}{ Domain } & \multirow{2}{*}{ Questions } & \multicolumn{5}{|c|}{ Mean Scores } \\
\hline & & SA & A & $\mathrm{N}$ & SD & $\mathrm{D}$ \\
\hline \multirow{6}{*}{$\begin{array}{l}\text { Reasons participants } \\
\text { identified led them to } \\
\text { enrollment in the four online } \\
\text { courses }\end{array}$} & I like asynchronous classes because I am an independent learner. & \multirow{6}{*}{$38 \%$} & \multirow{6}{*}{$34 \%$} & \multirow{6}{*}{$18 \%$} & \multirow{6}{*}{$7 \%$} & \multirow{6}{*}{$3 \%$} \\
\hline & I find it easy to express my thoughts in writing in the online format. & & & & & \\
\hline & Asynchronous learning gives me extra time to think. & & & & & \\
\hline & $\begin{array}{l}\text { I like the extra time the online format gives me to think about the } \\
\text { content of course materials. }\end{array}$ & & & & & \\
\hline & My family commitments prevent me from attending a weekly class. & & & & & \\
\hline & $\begin{array}{l}\text { The asynchronous format allows me to complete work } \\
\text { as my school permits. }\end{array}$ & & & & & \\
\hline \multirow{4}{*}{$\begin{array}{l}\text { Appropriateness of Readings } \\
\text { and Assignments }\end{array}$} & Course materials made me think outside the box. & \multirow{4}{*}{$32 \%$} & \multirow{4}{*}{$40 \%$} & \multirow{4}{*}{$11 \%$} & \multirow{4}{*}{$11 \%$} & \multirow{4}{*}{$6 \%$} \\
\hline & $\begin{array}{l}\text { Course readings challenged me to examine how I interact with K-12 } \\
\text { students. }\end{array}$ & & & & & \\
\hline & Course readings led me to change how I interact with K-12 students. & & & & & \\
\hline & $\begin{array}{l}\text { The collaborative work helped me create new ideas and think more } \\
\text { deeply about ways to plan instruction for English learners. }\end{array}$ & & & & & \\
\hline \multirow{2}{*}{ Technology Tools Used } & The technology tools were easily accessible. & \multirow{2}{*}{$37 \%$} & \multirow{2}{*}{$43 \%$} & \multirow{2}{*}{$11 \%$} & \multirow{2}{*}{$7 \%$} & \multirow{2}{*}{$2 \%$} \\
\hline & The Blackboard platform was easy to navigate. & & & & & \\
\hline \multirow{3}{*}{$\begin{array}{lr}\text { Quality of } & \text { Instructor } \\
\text { Feedback } & \text { and } \\
\text { Communication } & \end{array}$} & Instructor availability met my educational needs. & \multirow{3}{*}{$50 \%$} & \multirow{3}{*}{$24 \%$} & \multirow{3}{*}{$9 \%$} & \multirow{3}{*}{$9 \%$} & \multirow{3}{*}{$8 \%$} \\
\hline & Instructor feedback was timely and informative. & & & & & \\
\hline & Instructor was accepting of student's opinions. & & & & & \\
\hline \multirow{4}{*}{$\begin{array}{l}\text { Course Organization and } \\
\text { Format }\end{array}$} & The syllabus was well organized and student friendly. & \multirow{4}{*}{$51 \%$} & \multirow{4}{*}{$26 \%$} & \multirow{4}{*}{$14 \%$} & & \\
\hline & This course was more rigorous than a face-to-face class. & & & & & \\
\hline & $\begin{array}{l}\text { The online course format helped me manage my time and pace } \\
\text { myself to meet required deadlines. }\end{array}$ & & & & $7 \%$ & $2 \%$ \\
\hline & This course was as rigorous as a face-to-face class. & & & & & \\
\hline & Course activities were scaffolded well. & & & & & \\
\hline Achievement of Outcomes & $\begin{array}{l}\text { The number of individual assignments and group assignments was } \\
\text { balanced. }\end{array}$ & $31 \%$ & $38 \%$ & $7 \%$ & $15 \%$ & $9 \%$ \\
\hline & The readings helped me examine what I do in my classroom. & & & & & \\
\hline & Course materials helped me examine my philosophical stances. & & & & & \\
\hline & $\begin{array}{l}\text { The group work gave me ideas that I can use to engage my own } \\
\text { students in collaborative work. }\end{array}$ & & & & & \\
\hline & $\begin{array}{l}\text { Group assignments challenged me to examine course content and } \\
\text { clarify my ideas. }\end{array}$ & & & & & \\
\hline Student Collaboration & $\begin{array}{l}\text { The required group work showed me ways to promote professional } \\
\text { development in my school district. }\end{array}$ & $22 \%$ & $34 \%$ & $19 \%$ & $16 \%$ & $9 \%$ \\
\hline & $\begin{array}{l}\text { The required collaborative reflections helped me apply theory to } \\
\text { what takes place in the classroom context. }\end{array}$ & & & & & \\
\hline
\end{tabular}

\section{Appendix 2. Qualitative Data}

\begin{tabular}{|l|l|}
\hline \multirow{2}{*}{$\begin{array}{l}\text { Question: My one or two preferred assignments in } \\
\text { this course were: }\end{array}$} & Feedback \& Discussion: book club, group assignments, instructor comments \\
\cline { 2 - 2 } & Individual Reflections: language analysis project, quizzes, papers, lesson plan \\
\cline { 2 - 2 } & Course Organization \& Format: clarification needed, time consuming \\
\hline \multirow{2}{*}{$\begin{array}{l}\text { Question: Please share any positive or negative } \\
\text { comments about your online course experience: }\end{array}$} & $\begin{array}{l}\text { Quality of Instructor: timeliness, feedback, approachability } \\
\text { assignment load }\end{array}$ \\
\cline { 2 - 2 } & $\begin{array}{l}\text { Reasons for Enrollment: work commitment, time-management, family commitment, } \\
\text { individual pace }\end{array}$ \\
\cline { 2 - 2 } & \begin{tabular}{l} 
Technology: fixed completion time, internet accessibility, texting, accessibility \\
\hline
\end{tabular}
\end{tabular}




\section{REFERENCES}

[1] Abel, R. (2005). Achieving success in Internet-supported learning in higher education: Case studies illuminate success factors, challenges, and future directions. Alliance for Higher Educations Competiveness. Retrieved from www.a-hec.org/research/study_reports/IsLo205/TOC.html.

[2] Allen, I.E., \& Seaman, J. (2010). Class differences: Online education in the United States. Retrieved from http://files.eric.ed.gov/fulltext/ED529952.pdf

[3] Allen, I.E., \& Seaman, J. (2011). Going the distance. Online education in the United States. Babson Research Survey Group and Quahog Research Group, LLC. Retrieved from http://www.onlinelearningsurvey.com/reports/goingthedistan ce.pdf

[4] Allen, I.E., \& Seaman, J. (2013). Changing course: Ten years of tracking online education in the United States. Babson Research Survey Group and Quahog Research Group, LLC. Retrieved from

http://www.onlinelearningsurvey.com/reports/changingcours e.pdf

[5] Bates, T. (2011). Managing technology in higher education: Strategies for transforming teaching and learning. San Francisco: Jossey Bass.

[6] Chiero, R., \& Beare, P. (2010). An evaluation of online versus campus based teacher preparation programs. MERLOT, Journal of online journal and teaching, 6 (4), 1-11.

[7] Compton, L. (2009). Preparing language teachers to teach language online: a look at skills, roles, and responsibilities. Computer assisted language learning, 22, 73-79.

[8] Davis, D., \& Rose, R. (2007). Professional developments for virtual schooling and online learning. Retrieved February 26 2008 from http://www.nacol.org/docs/NACOL_PDforVSandOlnLrng.p df.

[9] Dede, C. Ketelhut, D.J., Whitehouse, P., Breit, L., \& Mc Closkey, E. M. (2009). A research agenda for online teacher professional development, 60, 8-19.

[10] [, C.M., \& Youngs, B.L. (2006). Teacher preparation for online language instruction. In P.Hubbard \& M. Levy (Eds.), Teacher education in CALL (pp. 267-282). Philadelphia: John Benjamins Publishing Company.

[11] Garner, W. E., Pack, T. G., Szirony, G. M. \& Beeson, E. T. (2013). Course delivery platform changes and instructional delivery methods: Student attitudes and perceptions. Universal Journal of Educational Research, 1(2), 48-56.

[12] Green, K. C., \&n Wagner, E. (2011). Online education: Where is it going? What should boards know? Trusteeship Magazine, Association of Governing Boards of Universities and Colleges. Retrieved from http://agb.org/trusteeship/2011/online-education-where-it-go ing-what-should-boards-know

[13] Kearsley, G. (2005). Online Learning. Personal reflection on the transformation of education. Englewood Cliffs, NJ: Educational Technology Publications.

[14] McNeals, R.B. Jr. (2015). Institutional environment(s) for online course development and delivery. Universal Journal of Educational Research, 3 (1), 46-54.

[15] Means, B., Toyama, Y., Murphy, R., Bakia, M., \& , K. (2009). Evaluation of evidence-based practices in online learning: A meta-analysis and review of online learning studies. Washington, D.C... Retrieved at http://www.ed.gov/rschstat/eval/tech/evidence-basedpractice s/finalreport.pdf.

[16] Meyer, K. (2008). If higher education is a right and distance education is the answer then who will pay? Sloan Consortium. Journal of Asynchronous Learning Networks, 12 (1), 45-68.

[17] Neal, R. B. (2015). Institutional environment(s) for online course development and delivery. Universal Journal of Educational Research, 31(1), 46-54.

[18] Neuhauser, C. (2002). Learning style and effectiveness of online and face-to-face instruction, The American Journal of Distance Education, 16 (2), 99-113.

[19] Palloff, R. M., \& Pratt, K. (2011). The excellent online instructor. Strategies for professional development. San Francisco, CA: Jossey-Bass.

[20] Patrick, S., \& Powell, A. (2009). A summary of research on the effectiveness of K-12 online learning. "Effectiveness of Online Teaching and Learning," iNACOL. Viena, VA: US. Retrieved from www.k12.com/sites/defailt/files/pdf/school-docs/NACOL_R esearchEffectiveness-hr.pdf

[21] Power, M. (2008). The emergence of a blended online learning environment. Retrieved from http://jolt.merlot.org/vo14no4/power_1208.htm

[22] Rothman, T., Romeo, L., Brennan, M., \& Mitchell, D. (2011). Criteria for assessing student satisfaction with online courses. International Journal for e-Learning Security (IJeLS), 1, 27-32. Retrieved from

http://www.infonomicssociety.org/IJeLS/Criteria\%20for $\% 20$ Assessing\%20Studen \%20Satisfaction\%20with\%20Online $\%$ 20Courses.pdf

[23] Sampson, P.M. \& Leonard, J., \& Ballenger, J.W., \& Coleman, J.C. (2010). Student satisfaction of online courses for educational leadership. Retrieved from http://www.westga.edu/ distance/ojdla/Fall133/sampson_bal lenger133.html

[24] Shachar, M. \& Neumann, Y. (2010). Twenty years of research on the academic performance of differences between traditional and distance learning: Summative meta-analysis and trend examination, MERLOT, Journal of Online Learning and Teaching, 6 (2), 318-334..

[25] Stephen, J. (2001). Teaching \& learning online: Pedagogies for new technologies. London: Kogan Page.

[26] Swan, K. (2003). Learning effectiveness: what the research tells us. In J. Bourne \& J. C. Moore (Eds) Elements of Quality Online Education, Practice and Direction. Needham, MA: Sloan Center for Online Education, 13-45. 
[27] Strauss, A, \& Corbin, J. (1990). Basics of qualitative research: Grounded theory, procedures, and techniques. Newbury Park, CA: Sage Publications.

[28] Twigg, C. A. (2001). Innovations in online learning: Moving beyond no significant difference. Retrieved from http://wwww.educasuse.edu/Resources/InnovationsinOnline LearningMov/155350.

[29] U.S. Department of Education. (2010). Evaluation of evidence-based practices in online Learning: A meta-analysis and review of online learning studies. Retrieved from. https://www2.ed.gov/rschstat/eval/tech/evidence-based-pract ices/finalreport.pdf

[30] Van Der Werf, M., \& Sabatier, G. (2009). College of 2020: Students. Retrieved from
http://www.uwec.edu/CETL/bundles/upload/college2020-dl. pdf

[31] Ward, M.E, \& Peters, G., \& Shelley, K. (2010). Student and faculty perceptions of the quality of online learning experiences. Retrieved from http://www.irrodl.org/index.php /irrodl/article/view/867/1610

[32] Wood, C. (2005). Highschool.com. Quality of online courses. Edutopia, 1(4), 32-37.

[33] Xu, D. \& Jaggars, S.S. (2013). Adaptability to online learning: Differences across types of students and academic subjects areas. Retrieved from http://anitacrawley.net/Reports/adaptability-to-online learning.pdf 